\title{
Pengembangan Perangkat Speech Recognition Bagi Penyandang Bisu Tuli Sebagai Sarana Komunikasi
}

\author{
Umrah Sahni ${ }^{1}$, Udin Sidik Sidin², Muhammad Riska ${ }^{3}$ \\ Jurusan Pendidikan Teknik Informatika dan Komputer, Universitas Negeri Makassar \\ Minasa upa blokJ7 no 22 \\ ${ }^{1}$ umrahsahni@gmail.com
}

\begin{abstract}
Abstrak - This study aims to produce a design for the development of speech recognition devices for deaf-mute people to make it easier for the public to communicate with deaf mute visitors during emergencies by using a sound sensor that is speech recognition. Data collection techniques used were observation, questionnaires and documentation. Then the data collected will be analyzed using descriptive analysis. The results of the study were obtained from 25 respondents in the SLB of South Sulawesi Province Development, resulting in an overall average response rate of $80 \%$ from the highest value of $100 \%$ and the lowest value of $0 \%$. This tool works with voice commands that have been done by the word train first first Then if the word is detected, the word will automatically appear on the LCD screen and simultaneously with the vibration produced by the vibrator. So it can be concluded that the speech recognition device for deaf mutes is good based on the respondent response category table.
\end{abstract}

Keywords : Deaf Mute, Speech Recognition, SLB,

\section{PENDAHULUAN}

\subsection{Latar Belakang}

Orang normal tidak banyak menemui hambatan dan kesulitan dalam melakukan mobilitas gerak di kesehariannya. Seseorang dapat pergi dari satu tempat ke tempat lain yang diinginkan dengan cepat untuk mencari dan memenuhi kebutuhan hidupnya. Selain itu, orang normal juga bisa berolahraga dengan nyaman karena tidak memiliki kekurangan panca indera (Baharuddin, 2015). Lain halnya dengan orang yang memiliki keterbatasan membuat seseorang merasa mempunyai masalah. Keterbatasan yang dialami seseorang bisa terjadi karena bawaan dari lahir atau karena kecelakaan. Seseorang yang terlahir dengan keadaan terbabatas disebut penyandang (disabilitas) yang membuat ruang gerak menjadi terbatas dan menimbulkan ketergantungan dengan orang lain (Maharani, 2018)

Orang yang memiliki kekurangan panca indera disebut dengan Anak Berkebutuhan Khusus (ABK), salah satunya bisu tuli. Dalam kehidupan sehari-hari berkomunikasi dengan penyandang bisu tuli, minimal harus berhadapan langsung dengannya dan menyatakan sesuatu dengan bahasa isyarat berupa gerakan tangan atau dengan melihat gerakan bibir, yang menjadi masalah besar adalah saat penyandang bisu tuli dipanggil dari arah luar atau pandangannya tidak tertuju pada orang yang mengajaknya berbicara, akan kesulitan dalam komunikasi yang tidak saling berhadapan sehingga dapat menjadi ancaman dalam kondisi tertentu di lingkungan berbahaya seperti jalan raya, lintasan kereta api, dan area berbahaya lainnya. Berdasarkan dari pengamatan peneliti yang pernah melihat seorang penyandang angbisu tuli yang sedang berjalan di jalan raya kemudian beberapa kendaraan dari arah belakang yang sangat laju dengan membunyikan kelaksonnya bersamaan teriakan peringatan dari orang sekitar tidak bisa di respon dengan cepat, alhasil pengendara tersebut menabrak penyandang bisu tuli. Kasus seperti itu tidak hanya terjadi satu atau dua kali saja, bahkan banyak peristiwa yang dapat membahayakan hidup penyandang bisu tuli ketika berada di tempat keramaian. Bagi penyandang bisu tuli yang kesulitan dalam mendapatkan informasi, terutama dalam keadaan darurat yang diluar batas pandangannya. Seperti teriakan peringatan dari orang lain, tidak akan dapat direspon dengan sigap karena memiliki kekurangan pendengaran. Hal tersebut berdampak terhadap kehidupannya secara kompleks terutama pada kemampuan berbahasa sebagai alat komunikasi yang sangat penting (Dhoni, dkk, 2018).

Penelitian yang dilakukakan oleh Liga (2017) melakukan perancangan aplikasi komunikasi penyandang tunarungu berbasis android. Pada penelitian ini memanfaatkan speech recognition untuk membantu dalam malakukan komunikasi dengan orang disekitar atau sebaliknya. Kekurangan dari penelitian ini adalah komunikasi tersebut hanya dapat berlangsung pada jarak dekat sehingga tidak memungkin dalam komunikasi pada jarak kurang dari 2 meter. 
Dilanjutkan penelitian oleh Wa Ode Septiana (2018) adalah merancang sebuah gelang getar shalat untuk penyandang tuli (Tunarungu). Penelitianya menggunakan GGS yaitu 2 pasang gelang yang dilengkapi dengan sensor jarak, mikrokontroller arduino pro mini dan modul NRF24I01 yang dipasang pada gelang imam dan makmum tuli. Sistem kerja GGS adalah ketika imam berubah gerakan sholat, maka sensor yang terdapat pada gelang imam akan memberi sinyal kepada gelang makmum sehingga bergetar. Dengan demikian makmum dapat mengetahui bahwa imam telah merubah posisi saat sholat.

Perkembangan teknologi yang pesat memberikan banyak solusi terhadap permasalahan kehidupan bagi penyandang bisu tuli, termasuk pendekatan terkait masalah komunikasi. Kurangannya kemampuan dalam mendengar dan berbicara, penyandang bisu tuli masih memiliki sensifitas terhadap sentuhan teknologi. Pengebangan alat yang dilakukan peneliti dilakukan untuk memberi kemudahan masyarakat berinteraksi dengan penyandang bisu tuli pada keadaan darurat. Berdasarkan penelitian ini kemudian peneliti melakukan pengembangan dengan meracang pengembangan perangkat speech recognition bagi penyandang bisu tuli untuk di gunakan di luar ruangan yang berinteraksi langsung dengan masyarakat. perangkat ini dapat digunakan terutama dalam keadaan darurat karena seringkali penyandang bisu tuli dihadapkan ancaman bahaya ketika diluar ruangan,

Teknologi Speech Recognition berkembang dengan pesat dan dapat dimanfaatkan untuk menciptakan teknologi komunikasi bagi para penyandang bisu tuli. Dengan mengkonversi perintah suara atau kata ke dalam bentuk gerakan sentuhan yang dapat langsung dirasakan. Alat ini diintegrasikan dalam sebuah perangkat speech recognition yang memiliki kemapuan menangkap suara, mengenali suara yang telah diprogramkan (speech recognition), dan mengubah jenis perintah suara menjadi gerakan tuas (vibrator) sentuhan ke kulit sebagai kode kata tertentu yang dapat dikenali oleh penderita bisu tuli.

\subsection{Rumusan Masalah}

Berdasarkan uraian dan penjelasan yang telah dikemukakan pada latar belakang maka rumusan masalah yang akan dikaji dalam penelitian ini yaitu:

1) Bagaimana hasil pengembangan perangkat speech recognition sebagai sarana komunikasi pada penyandang bisu tuli?

2) Bagaimana hasil pengujian perangkat speech recognition sebagai sarana komunikasi pada penyandang bisu tuli?

3) Bagaimana tanggapan pengguna mengenai pengembangan perangkat speech recognition sebagai sarana komunikasi pada penyandang bisu tuli?.

\subsection{Tujuan Pengembangan}

Tujuan dilakukannya pengembangan ini adalah

1) Untuk mengetahui hasil pengembangan perangkat speech recognition sebagai sarana komunikasi pada penyandang bisu tuli.

2) Untuk mengetahui hasil pengujian perangkat speech recognition sebagai sarana komunikasi pada penyandang bisu tuli.

3) Untuk mengetahui tanggapan pengguna mengenai pengembangan perangkat speech recognition sebagai sarana komunikasi pada penyandang bisu tuli.

\subsection{Manfaat Pengembangan}

Manfaat penilitian ini adalah sebagai berikut;

1) Bagi Masyarakat;

Memudahkan masyarakat umum dalam berkomunikasi dengan para penyandang bisu tuli pada saat keadaan darurat

2) Bagi Disabilitas Penyandang bisu tuli

Memberikan kemudahan penyandang bisu tuli dalam mendapatkan informasi dari masyarakat sekitar pada saat keadaan darurat.

3) Bagi Peneliti

Menambah pengetahuan terhadap penggunaan alat-alat mikrokontroler dan memberikan kemudahan bagi penyadang bisu tuli dalam mendapatkan informasi dari masyarakat umum pada saat keadaan darurat

\section{KERANGKA BERFIKIR}

Ketunarunguan (tuli) bukan hanya mengakibatkan tidak berkembangnya kemampuan berbicara, lebih dari itu dampak paling besar adalah terbatasnya kemampuan berbahasa mengemukakan bahwa masalah utama penyandang tuna rungu bukan terletak pada tidak dikuasainya suatu sarana komunikasi lisan, melainkan akibat hal tersebut terhadap perkembangan kemampuan berbahasanya secara keseluruhan yaitu mereka tidak atau kurang mampu dalam memahami lambang dan aturan bahasa. Secara lebih spesifik, mereka tidak mengenal atau mengerti lambang/kode atau 'nama' yang digunakan lingkungan guna mewakili benda-benda, peristiwa kegiatan, dan perasaan serta tidak memahami aturan/sistem/tata bahasa. Keadaan ini terutama dialami anak tunarungu yang mengalami ketulian sejak lahir, usia dini atau tuli prabahasa.Dalam pemberian gaji terdapat berbagai macam jenis gaji yang diberikan kepada karyawan yang merupakan hak bagi karyawan untuk mendapatkannya seperti gaji pokok, tunjangan, lembur serta pengembalian uang karyawan yang sebelumnya ada biaya-biaya tertentu yang karyawan tersebut mengeluarkan uang sendiri kemudian diganti oleh perusahaan [12].

Terhambatnya kemampuan berbahasa yang dialami anak tuna rungu (tuli), berimplikasi pada kebutuhan khusus mereka untuk mengembangkan kemampuan berbahasa dengan metode

\section{P-ISSN 2656-1247 and E-ISSN 2715-5919}


khusus, yang merupakan dasarnya setiap anak tunarungu dapat dikembangkan kemampuan berbahasa dan berbicaranya melalui berbagai layanan khusus dan fasilitas khusus yang sesuai dengan kebutuhannya. Oleh karena itu perlu pengembangan perangkat speech recognition dalam memudahkan seseorang berkomunikasi dengan para disibilitas tuna rungu dan tuna wicara/bisu tuli.

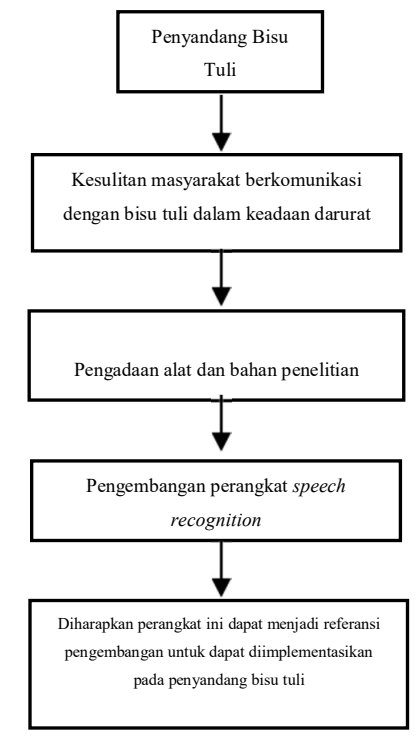

Gambar 1. Bagan Kerangka Pikir

\section{METODE PENELITIAN}

Jenis penelitian yang digunakan adalah pengembangan dan penelitian atau research and development. Menurut Sugiyono (2015: 407) metode penelitian dan pengembangan R \& D merupakan metode penelitian yang digunakan untuk

menghasilkan produk tertentu, dan menguji keefektifan dari produk tersebut.

Desain penelitian ini menggunakan model pengembangan 4-D (four-D). Model penelitian dan pengembangan model 4D terdiri dari 4 tahapan yaitu define, design, develop dan disseminate (Thiagarajan, 1974: 5). Model pengembangan 4D dapat diadaptasi menjadi 4P, yaitu pendefinisian, perancangan, pengembangan dan penyebaran. Penelitian ini di laksanakan pada bulan Juni sampai Desember 2019. Penelitian ini dilaksanakan di SLB (Sekolah Luar Biasa) Negeri, Pembina Provinsi Sul-Sel, Jln Dg. Tata Parang Tambung, Makassar.
Ujicoba produk juga merupakan syarat yang harus dikerjakan oleh peneliti dalam mengambil penelitian model pengembangan. Pada tahap pengujian perangkat speech reognition penyandang bisu tuli ini dilakukan di SLB Pembinaan Provinsi Sulawesi Selatan. Sebelum dilakuakan uji coba di SLB, perangkat terlebih dahulu dilakuakan validator oleh ahli.

Pelaksanaan uji kelayakan dilakukan dengan cara menyerahkan produk pengembangan beserta kuisioner penilaian kepada validator (Ahli) untuk menilai layak atau tidaknya produk pengembangan serta memberikan kritik dan saran perbaikan. Setelah dilakuakan validasi kemudian perangkat kemudian di uji coba di SLB. Instrumen pengumpulan data dalam penelitian ini adalah observasi, angket dan dokumentasi.

\section{HASIL DAN PEMBAHASAN}

\subsection{Perakitan Keseluruhan Komponen Perangkat speech recognition}

Setelah perakitan satu persatu komponen ke mikrokontroller selesai di uji coba, kemudian akan dilanjutkan ketahap yang paling penting yaitu perakitan secara keseluruhan pada komponen. Semua komponen di dihubungkan menjadi satu pada papan PCB (Printed Circuid Board) dan dilakukan uji coba pada program gabungan yang telah dibuat. Cara kerja perangkat pada perakitan gabungan ini adalah dengan menyimpan program gabungan yang telah dibuat sebelumnya ke mikrokontroller sehingga pada saat program di compile maka program secara otomatis tersimpan. Setelah itu, dilakukan uji coba dengan menggunakan kata berhenti. Apabila kata tersebut dideteksi oleh speech recognition maka akan secara otomatis kata berhenti akan muncul di lcd dan secara bersamaan vibrator akan bergetar.

\subsubsection{Uji Coba Produk Pada Beberapa Kondidi}

Uji coba alat dilakukan pada dua kondisi yang berbeda yaitu uji coba pada tempat yang tenang dan uji coba di tempat yang ramai. Untuk mengetahui berapa jauh jarak yang akurat untuk mendeteksi suara pada sensor pengenalan suara yang di programkan pada speech recognition. Percobaan penegenalan di tempat ramai dilakukan di KFC Pettarani dan percobaan pengenalan suara di tempat tenang dilakukan di Pondok 4 dara. hasil dari pengujian efesiensi penggunaan alat ini dapat di lihat pada Tabel 4.5 dan Tabel 4.6 sebagai berikut.

\section{P-ISSN 2656-1247 and E-ISSN 2715-5919}


4.1.2 Uji Coba Produk Pada Responden

Responden merupakan 25 siswa siswi penyandang bisu

Tabel 1. Uji coba jarak dan akurasi suara di tempat ramai

\begin{tabular}{|c|c|c|c|c|}
\hline $\begin{array}{c}\text { Per } \\
\text { c }\end{array}$ & Kata & $\begin{array}{c}\text { Jara } \\
\text { k } \\
\text { (m) }\end{array}$ & Reaksi & Keterangan \\
\hline \multirow{2}{*}{1} & Berhenti & \multirow{2}{*}{0.5} & \multirow{2}{*}{ Tepat } & \multirow{2}{*}{ Terdeteksi } \\
\hline & Jangan & & & \\
\hline \multirow{2}{*}{2} & Berhenti & \multirow{2}{*}{1} & \multirow{2}{*}{$\begin{array}{l}\text { Tidak } \\
\text { tepat }\end{array}$} & \multirow{2}{*}{ Tidak terdeteksi } \\
\hline & Jangan & & & \\
\hline \multirow{2}{*}{3} & Berhenti & \multirow{2}{*}{1.2} & \multirow{2}{*}{$\begin{array}{l}\text { Tidak } \\
\text { tepat }\end{array}$} & \multirow{2}{*}{ Tidak terdeteksi } \\
\hline & Jangan & & & \\
\hline \multirow{2}{*}{4} & Berhenti & \multirow{2}{*}{2} & \multirow{2}{*}{$\begin{array}{l}\text { Tidak } \\
\text { tepat }\end{array}$} & \multirow{2}{*}{ Tidak Terdeteksi } \\
\hline & Jangan & & & \\
\hline \multirow{2}{*}{5} & Berhenti & \multirow{2}{*}{3} & \multirow{2}{*}{$\begin{array}{l}\text { Tidak } \\
\text { tepat }\end{array}$} & \multirow{2}{*}{ Tidak Terdeteksi } \\
\hline & Jangan & & & \\
\hline
\end{tabular}

Berdasarkan pada Tabel 1. dapat disimpulkan bahwa Uji coba jarak dan akurasi pengenalan suara di tempat ramai untuk kata berhenti dan jangan pada jarak $0,5 \mathrm{~m}$ dapat terdeteksi, untuk kata berhenti dan jangan pada jarak 1-3 m tidak dapat terdeteksi.

Tabel 2. Uji coba jarak dan akurasi suara di tempat

\begin{tabular}{|c|c|c|c|c|}
\hline Perc & Kata & Jarak & reaksi & Keterangan \\
\hline \multirow{2}{*}{1} & Berhenti & \multirow{2}{*}{0.5} & \multirow{2}{*}{ Tepat } & \multirow{2}{*}{ Terdeteksi } \\
\hline & Jangan & & & \\
\hline \multirow{2}{*}{2} & Berhenti & \multirow{2}{*}{1} & \multirow{2}{*}{ Tepat } & \multirow{2}{*}{ Terdeteksi } \\
\hline & Jangan & & & \\
\hline \multirow{2}{*}{3} & Berhenti & \multirow{2}{*}{1.2} & \multirow{2}{*}{ Tepat } & \multirow{2}{*}{ Terdeteksi } \\
\hline & Jangan & & & \\
\hline \multirow{2}{*}{4} & Berhenti & \multirow{2}{*}{2} & \multirow{2}{*}{ Tepat } & \multirow{2}{*}{ Terdeteksi } \\
\hline & Jangan & & & \\
\hline \multirow{2}{*}{5} & Berhenti & \multirow{2}{*}{3} & \multirow{2}{*}{ Tepat } & \multirow{2}{*}{ Terdeteksi } \\
\hline & Jangan & & & \\
\hline
\end{tabular}

Berdasarkan pada Tabel 2. dapat disimpukan bahwa Uji coba jarak dan akurasi pengenalan suara di tempat tenang untuk kata berhenti dan jangan pada jarak 0,5-3 $\mathrm{m}$ dapat terdeteksi. tuli pada Sekolah Luar Biasa (SLB) Untuk mendapatkan hasil tanggapan responden, dilakukan uji coba terlebih dahulu di depan siswa siswi pada sekolah tersebut secara satu per satu. Adapun hasil tanggapan responden dapat dilihat pada Tabel 4.3

Tabel 3. Statistik deskripsti

responden

\begin{tabular}{|c|c|c|c|c|c|c|c|}
\hline Perny. & $\mathrm{N}$ & Min & Max & Sum & Mean & $\begin{array}{c}\% \text { mean } \\
(\%)\end{array}$ & Kategori \\
\hline 1 & 25 & 1 & 1 & 25 & 1.00 & 100 & Sangat \\
\hline 2 & 25 & 0 & 1 & 22 & .88 & 88 & $\begin{array}{c}\text { Sangat } \\
\text { Valid }\end{array}$ \\
\hline 3 & 25 & 0 & 1 & 10 & .40 & 40 & $\begin{array}{c}\text { Kurang } \\
\text { Valid }\end{array}$ \\
\hline 4 & 25 & 0 & 1 & 24 & .96 & 96 & $\begin{array}{c}\text { Sangat } \\
\text { Valid }\end{array}$ \\
\hline 5 & 25 & 0 & 1 & 20 & .80 & 80 & Valid \\
\hline 6 & 25 & 0 & 1 & 19 & .76 & 76 & Valid \\
\hline 7 & 25 & 0 & 1 & 24 & .96 & 96 & $\begin{array}{c}\text { Sangat } \\
\text { Valid }\end{array}$ \\
\hline 8 & 25 & 1 & 1 & 25 & 1.00 & 100 & $\begin{array}{c}\text { Sangat } \\
\text { Valid }\end{array}$ \\
\hline 9 & 25 & 0 & 1 & 24 & .96 & 96 & $\begin{array}{c}\text { Sangat } \\
\text { Valid }\end{array}$ \\
\hline 10 & 25 & 0 & 1 & 7 & .28 & 26 & $\begin{array}{c}\text { Kurang } \\
\text { Valid }\end{array}$ \\
\hline Valid N & 25 & & & & & & \\
\hline \multicolumn{5}{|c|}{ RATA-RATA KESELURUHAN } & 80 & 80 & Valid \\
\hline
\end{tabular}

Tabel 3 menggambarkan perolehan nilai pada setiap pernyataan yang digambarkan dengan Jumlah (sum) dan Nilai Rata-Rata (mean) hasil tanggapan responden. Jumlah (sum) didapatkan dengan menjumlah nilai hasil tanggapan 25 responden. Kemudian mean didapatkan dengan merata-ratakan jumlah nilai tanggapan responden yang didapatkan dengan cara 
membagi jumlah nilai (sum) dengan jumlah responden yaitu sebanyak 25 responden. Hal ini dilakukan pada masing-masing pernyataan, mulai dari pernyataan pertama sampai dengan pernyataan ke-sepuluh. Adapun Rata-Rata Keseluruhan didapatkan dengan menjumlahkan nilai mean pernyataan pertama hingga pernyataan ke-sepuluh kemudian dibagi dengan jumlah pernyataan yaitu 10. Hasil yang didapatkan, Rata-Rata Keseluruhan nilai tanggapan responden adalah sebesar $80 \%$ dari nilai tertinggi $100 \%$ dan nilai terendah adalah $0 \%$.

\section{KESIMPULAN DAN SARAN}

\subsection{Kesimpulan}

Setelah melakukan perancangan dan realisasi perangkat speech recogntion bagi Penyandang Bisu Tuli Sebagai Sarana Komunikasi dalam bentuk perangkat dan kemudian dilakukan pengujian terhadap alat, baik pengujian setiap blok atau keseluruhan. Pada tahap uji coba perangkat speech recognition dapat mendeteksi 2 kata yang disimpan yaitu kata berhenti dan jangan dengan jumlah train kata berhenti sebanyak 4 dan kata jangan sebanyak 3 . Hasilnya adalah kata yang di ucapkan dapat dideteksi pada jarak kurang dari 5 meter pada tempat tenang sedangkan pada tempat ramai jarak deteksi kata hanya sampai kurang dari 1 meter. Alat getar (vibrator) yang digunakan bekerja sangat baik dan dapat bergetar apabila kata terdeteksi. Hasil penelitian didapatkan dari 25 responden yang ada di SLB Pembinaan Provinsi Sulawesi Selatan menghasilkan rata-rata keseluruhan nilai tanggapan responden adalah sebesar $80 \%$ dari nilai tertinggi $100 \%$ dan nilai terendah $0 \%$. Maka dapat disimpulkan bahwa perangkat speech recognition bagi penyandang bisu tuli ini valid berdasarkan tabel kategori tanggapan responden.

\subsection{Saran}

Berdasarkan kesimpulan diatas maka saran yang dapat diajukan untuk peneliti selanjutnya adalah sebagai berikut.

1. Penggunaan sensor suara dengan spesifikasi yang lebih tinggi dan dapat mendeteksi suara lebih akurat pada keadaan apapun.

2. Penggunaan hardware (komponen) lebih kecil sehingga dapat dikembangakan menjadi implementasi gelang pintar berbasis suara pada penyandang bisu tuli

Penggunaan mikrokontroller dengan spesifikasi yang lebih tinggi agar dapat menyimpan lebih banyak perintah.

\section{DAFTAR PUSTAKA}

[1] Baharuddin, Ahmad. 2015. Pengembangan Alat Bantu Pembelajaran Tongkat Dengan sistem Kerja Line Follower Berbasis Mikrokontroler Atmega 32 Pada Anak Berkebutuhan Khusus "Tunanetra" Untuk Olahraga Atletik Nomor Jalan Cepat.Universitas Negeri Yogyakarta: Yogyakarta
[2] Maharani, Swasti, Yuni N, Tri A.P, Very, L.H, Astri D \& Nur, F.I. 2018. Pelatihan bisol bagi penyandang Tunarungu dan Tunawicara di SLB PSM Tekaran Sebagai Bekal Berwirausha. Jurnal Pengabdian Kepada Masyarakat, vol. 3, nomor 2, (https://jurnal.ugm.ac.id, diakses 26 April 2019).

[3] Septiana, Wa Ode Anastasia, Muqtafa, AW., Cahudin 2018. GGS (Gelang Getar Sholat) Alat Deteksi Gerak Sholat Imam untuk Makmum Tuli. Jurnal Transistor Elektro dan Elektronika, vol. 3, nomor 2, (https://docplayer.info, dikases 19 Mei 2019).

[4] Liga, Wendy, Erick F, \& Hendri. 2017. Perancangan Aplikasi Komunikasi Penyandang Tunarungu Berbasis Android. Processor. Jurnal Processor, Vol 12, Nomor 1, (ejournal.stikom-db.ac.id, diakses 12 April 2019).

[5] Sugiyono. 2018. Metode Penelitian Kuantitatif, Kualitatif dan R \& D. Bandung: Alfabeta

\section{P-ISSN 2656-1247 and E-ISSN 2715-5919}

